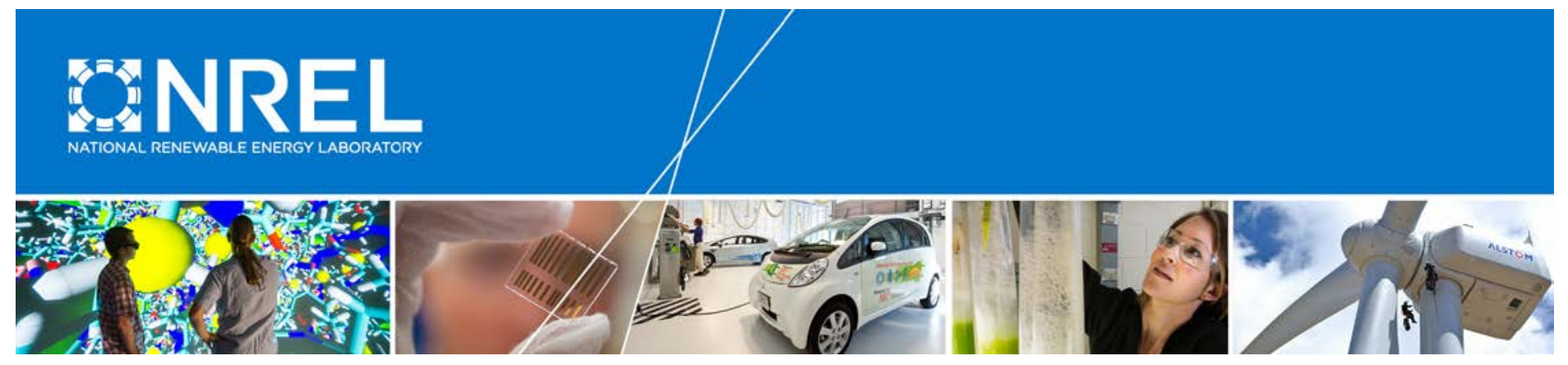

\title{
Selecting Solar: Insights into Residential Photovoltaic (PV) Quote Variation
}

Carolyn Davidson and Robert Margolis National Renewable Energy Laboratory

NREL is a national laboratory of the U.S. Department of Energy Office of Energy Efficiency \& Renewable Energy Operated by the Alliance for Sustainable Energy, LLC

This report is available at no cost from the National Renewable Energy Laboratory (NREL) at www.nrel.gov/publications.

Technical Report

NREL/TP-6A20-64792

October 2015 


\section{Selecting Solar: Insights into Residential Photovoltaic (PV) Quote Variation}

Carolyn Davidson and Robert Margolis National Renewable Energy Laboratory

Prepared under Task No. SM13.0590
NREL is a national laboratory of the U.S. Department of Energy Office of Energy Efficiency \& Renewable Energy Operated by the Alliance for Sustainable Energy, LLC

This report is available at no cost from the National Renewable Energy Laboratory (NREL) at www.nrel.gov/publications.

\section{Technical Report}

NREL/TP-6A20- 64792

October 2015

Contract No. DE-AC36-08GO28308
National Renewable Energy Laboratory 15013 Denver West Parkway

303-275-3000 • www.nrel.gov 


\title{
NOTICE
}

This report was prepared as an account of work sponsored by an agency of the United States government. Neither the United States government nor any agency thereof, nor any of their employees, makes any warranty, express or implied, or assumes any legal liability or responsibility for the accuracy, completeness, or usefulness of any information, apparatus, product, or process disclosed, or represents that its use would not infringe privately owned rights. Reference herein to any specific commercial product, process, or service by trade name, trademark, manufacturer, or otherwise does not necessarily constitute or imply its endorsement, recommendation, or favoring by the United States government or any agency thereof. The views and opinions of authors expressed herein do not necessarily state or reflect those of the United States government or any agency thereof.

This report is available at no cost from the National Renewable Energy Laboratory (NREL) at www.nrel.gov/publications.

Available electronically at SciTech Connect http:/www.osti.gov/scitech

Available for a processing fee to U.S. Department of Energy and its contractors, in paper, from:

\author{
U.S. Department of Energy \\ Office of Scientific and Technical Information \\ P.O. Box 62 \\ Oak Ridge, TN 37831-0062 \\ OSTI http://www.osti.gov \\ Phone: 865.576.8401 \\ Fax: 865.576.5728 \\ Email: reports@osti.gov
}

Available for sale to the public, in paper, from:

\author{
U.S. Department of Commerce \\ National Technical Information Service \\ 5301 Shawnee Road \\ Alexandria, VA 22312 \\ NTIS http://www.ntis.gov \\ Phone: 800.553 .6847 or 703.605 .6000 \\ Fax: 703.605.6900 \\ Email: orders@ntis.gov
}




\section{Acknowledgments}

This work was made possible by the Solar Energy Technologies Program at the U.S. Department of Energy (DOE). The authors wish to thank Laura Vimmerstedt, Ben Sigrin, Varun Rai, and Jarett Zuboy for providing review and feedback. In particular, the authors would like to thank Vikram Aggarwal of EnergySage for generously providing the data for this study as well as ongoing consult regarding the analysis. 


\section{List of Acronyms}

ITC

PPA

PV

Q

SREC

TPO
Investment Tax Credit

Power purchase agreement

Photovoltaic(s)

Quarter (e.g., Q2 $2015=$ second quarter of 2015)

Solar Renewable Energy Credit

Third-party-owned 


\section{Executive Summary}

Although U.S. deployment of residential solar photovoltaics (PV) has grown dramatically over the past decade, barriers to more widespread penetration remain. One barrier is the complexity of PV system purchases. Potential PV consumers must weigh many payment and ownership options, as well as physical attributes, including the percentage of electricity load to offset and the use of premium versus standard equipment. Before investing in a system, a prospective PV customer must not only have initial concept "buy-in," but also be able to evaluate the tradeoffs associated with different system parameters.

In particular, the lack of price transparency has important implications for PV diffusion. It suggests that, in addition to the effort involved with evaluating PV system parameters, prospective customers might need to evaluate disparate costs for each system attribute by comparing multiple bids. The difficulty of making such an evaluation with limited information can create a cognitive barrier to proceeding with the investment.

This analysis leverages recently available data from EnergySage, an online solar marketplace, to offer the first data-driven characterization of quote variation faced by prospective PV customers, lending early insight into the decisions customers face once they have initial buy-in. Major findings from our analysis of these data include the following:

- Residential properties exhibited a median range of $\$ 1.41 / \mathrm{W}$ between the highest and lowest quoted price during 2013-2015. The range decreased during this period: to a range of $\$ 0.79 / \mathrm{W}$ (for host-owned systems) and $\$ 0.54 / \mathrm{W}$ (for third-party-owned systems) in the first half of 2015.

- On average during 2013-2015, quotes for a given residential property had a range of 2 $\mathrm{kW}$ between the highest and lowest quoted PV system capacity. The range declined over this period from an average of $2.2 \mathrm{~kW}$ in 2013 to $1.8 \mathrm{~kW}$ in 2015 .

- Nearly half of the residential properties $(42 \%)$ received at least one quote for nonstandard equipment (high-efficiency panels, microinverters, or optimizers) in addition to a quote for standard equipment.

This suggests that even after a customer expresses initial interest in PV, the process of choosing a particular PV system is complex. Reducing this complexity would likely increase adoption. One particular complexity - the variation in quote prices and system sizes for systems quoted for the same property are declining over time in this data. It is not clear whether this is a result of price discovery around specific attributes of PV systems, a general convergence of PV prices around the value of PV for a particular household, or some other factor. Our results are limited by the fact that the quote data cover only a short period, and the numbers and geographies of quote contributors (i.e., installers) varied substantially over the course of this period. As they continue to grow, EnergySage and other quote-data sources likely will provide increasing insights into the progress toward standard, transparent, and consistent PV pricing. 


\section{Table of Contents}

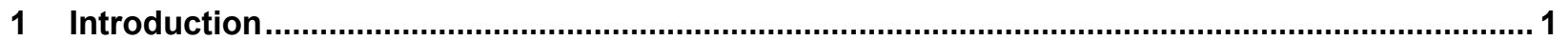

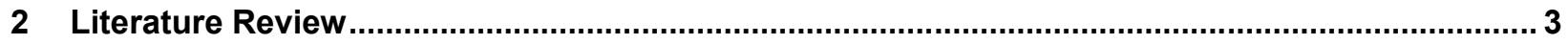

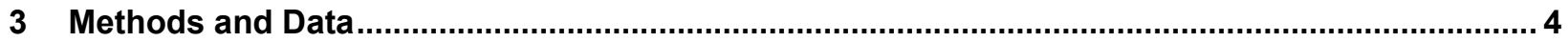

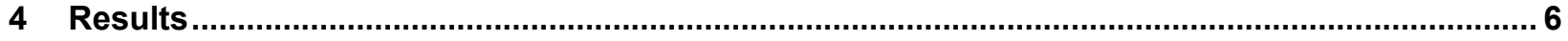

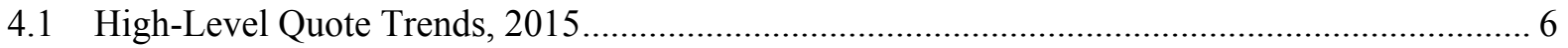

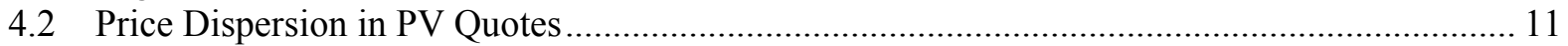

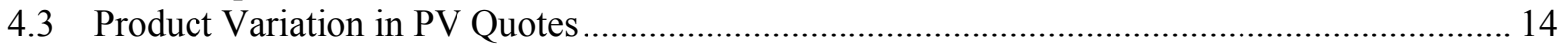

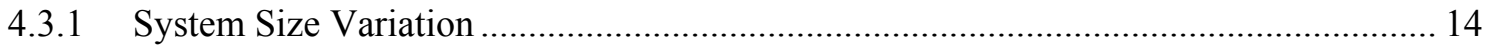

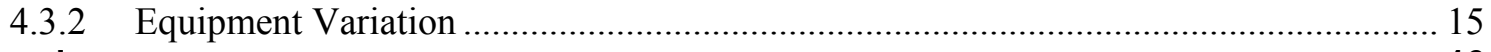

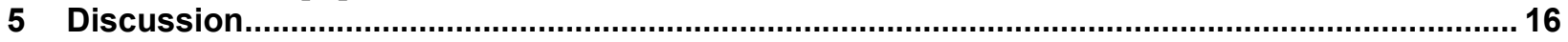

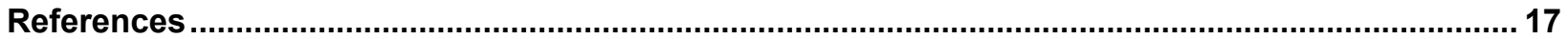

\section{List of Figures}

Figure 1. Illustration of possible prospective customer choice set ..................................................... 1

Figure 2. Percentage of properties receiving a given number unique installer quotes .......................... 4

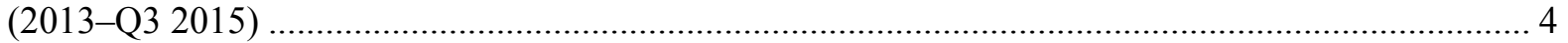

Figure 3. Distribution of EnergySage residential PV price quotes by state, 2015 ........................... 6

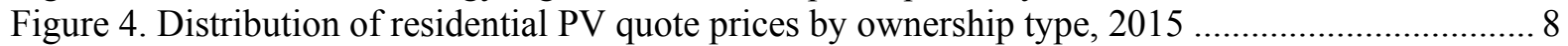

Figure 5. Host-owned residential PV price quotes by state: SREC and non-SREC markets, 2015 ...... 9

Figure 6. Median System Size and Distribution of Annual Energy Offset, 2015 ........................... 10

Figure 7. Range and standard deviation of residential PV quotes by property, 2013-Q2 2015......... 12

Figure 8. Distribution of quoted residential PV price ranges, by property and ownership model ...... 13

Figure 9. Range of quoted residential PV system sizes, for a given property ................................... 15

\section{List of Tables}

Table 1. Average Quote Price by Hardware Type, 2015 …........................................................... 7

Table 2. Mean Residential PV Quote Price by Ownership Type and Year......................................... 8

Table 3. Median Energy Sage and Tracking the Sun (Barbose and Darghouth 2015) Host-Owned

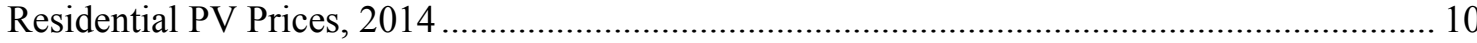




\section{Introduction}

The deployment of distributed residential solar photovoltaics (PV) in the United States continues to grow exponentially, from $27 \mathrm{MW}$ of new installed capacity in 2005 to $1.2 \mathrm{GW}$ of new installed capacity in 2014 (GTM Research and SEIA 2015). With growing demand, the PV installer landscape has evolved from small local or regional roofing companies in limited markets to a complex web of businesses ranging from small local installers to national vertically integrated solar service providers (GTM Research 2015). However, PV is still only installed on a small fraction of houses (less than $1 / 10^{\text {th }}$ of a percent). ${ }^{1}$ There are several reasons for this low market penetration. First, PV remains relatively expensive, similar to the financial outlay for a new car or a large home remodel, particularly if cash purchased. PV businesses are addressing this barrier by offering third-party financing options and, more recently, low-cost loans. Second, a PV purchase is a complex, high-commitment purchase. Potential PV consumers must weigh many payment and ownership options, as well as physical attributes, including the percentage of electricity load to offset and the use of premium versus standard equipment. Often prospective customers may solicit quotes from multiple installers, and each installer may provide multiple financing options, each with a corresponding price and payment schedule. Figure 1 illustrates a purely hypothetical example of the suite of system size, equipment, and financing choices that may be available for one example prospective customer.
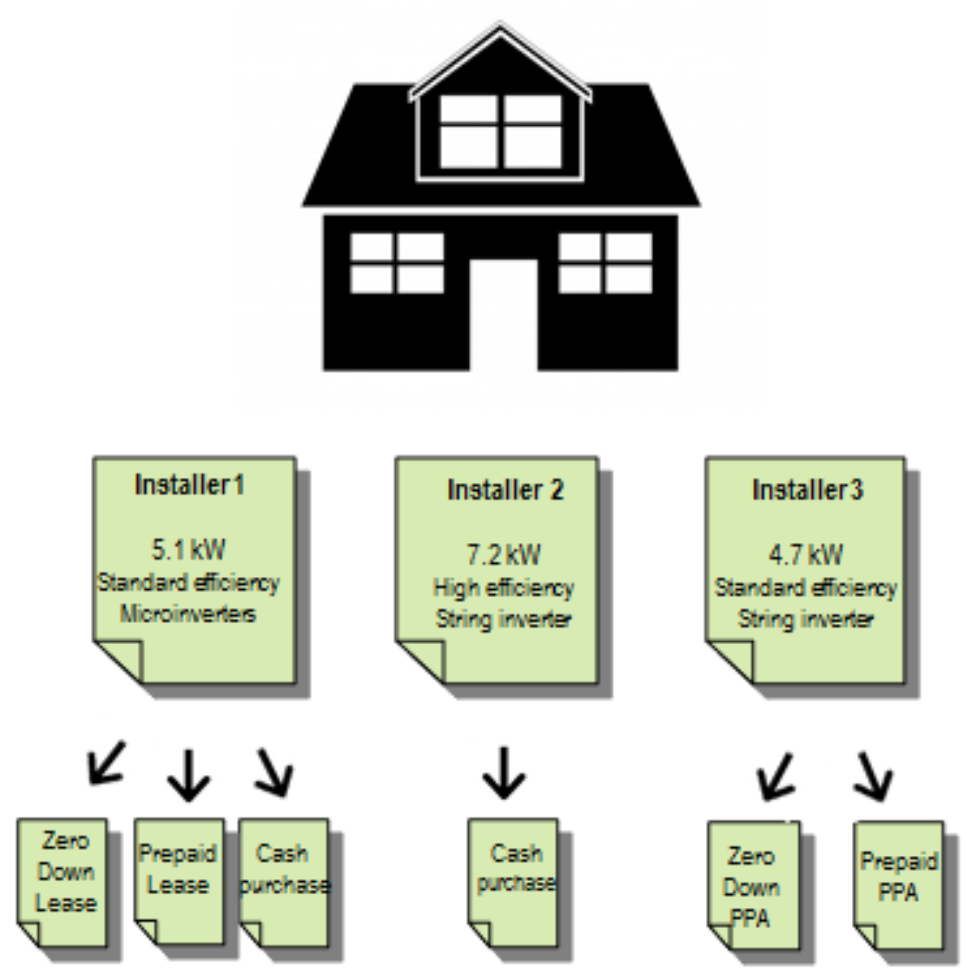

Figure 1. Illustration of possible prospective customer choice set

\footnotetext{
${ }^{1}$ As of 2014, solar had been installed on approximately 300,000 households (LBNL, 2015). There are currently approximately 70,000,000 single-family detached houses in the United States (U.S Department of Commerce, 2015).
} 
As a result, before investing in a system, a prospective PV customer must not only have initial concept "buy-in," but also be able to evaluate the performance and price tradeoffs associated with different system parameters. The effects of these decisions are long-lasting as an investment is, for all purposes, unchangeable.

Existing analysis suggests substantial dispersion in installed PV system prices (Davidson and Steinberg 2013; Gillingham et al. 2014). Classical economic theory posits that, in a competitive market with full information, each system attribute will be associated with a corresponding price, as with the Kelley Blue Book's used-car information. Although research has allocated some PV price dispersion to variation in system parameters, location, and business model, much remains unexplained. This lack of price transparency has important implications for PV diffusion. It suggests that, in addition to the effort involved with evaluating system parameters, prospective customers might need to evaluate disparate costs for each attribute by comparing multiple bids from different companies, and the difficulty of making such an evaluation with limited information may create a cognitive barrier to proceeding with the investment.

This paper leverages a recently available data set to begin to characterize the menu of options available to prospective residential PV customers. Using these data, we can begin to evaluate the consistency and complexity of PV quotes and attributes. Namely, we can evaluate the following questions:

1. What are the ranges of system design parameters for quotes for the same property?

2. Does price dispersion exist within quotes for the same property?

3. What metrics can we use to characterize quote complexity and price dispersion and track this variation over time?

This report is organized as follows. Section 2 discusses literature pertaining to the role of decision making, search costs, and price dispersion in general and with specific reference to the PV market. Section 3 describes our data and methods. Section 4 presents our results, including a high-level summary of the full data set and analyses of quoted prices, systems sizes, and PV equipment at the individual household level. Finally, Section 5 discusses the relevance of our findings to PV market growth. 


\section{Literature Review}

A growing body of literature about variables impacting PV diffusion addresses the consumer decision making process, particularly the importance of social networks and peer effects in reducing barriers to adoption (Noll et al. 2014; Bollinger and Gillingham 2012; Rai and Robinson 2013). The relatively few studies of the information-search process and decision making once a prospective PV customer considers adopting suggest that the informationgathering process can be prohibitive. Based on survey data, Rai and McAndrews (2012) found that PV adopters spent a moderate to large amount of time in the information-search process, mostly in understanding financial and performance parameters. Evaluating financial parameters is complicated because no "law of one price" exists in the residential PV market. Rather, price dispersion has been well documented within states and within similar system sizes (Davidson et al. 2015), even when controlling for labor costs and other cost drivers (Davidson and Steinberg 2013; Gillingham et al. 2014).

Online PV marketplaces that have surfaced in the last few years could reduce prospective buyers' search costs for acquiring PV price and product information (Bakos 1997). Enabling comparison of both price and product information is important, because PV systems vary in design, components, and sizing, making the PV market a differentiated market rather than a commodity market in which all products are identical (Bakos 1997). A sizeable body of literature has evaluated the role of online marketplaces in reducing market failures, including those associated with search costs and price dispersion; Chiang (2006) and Dinerstein et al. (2014) provide overviews.

Previous studies have been limited by the fact that PV adoption data are typically available from two sources: household surveys and state or utility incentive programs. These sources are limited in their ability to characterize options available to a consumer, because they rely on selfreporting of complex choices (household surveys) or the final elected choice only (incentive programs).

Our analysis builds on and helps fill the gaps in the existing literature. Drawing on a new data set - information from an online PV-quote provider - it offers the first data-driven characterization of quote variation faced by prospective PV customers, lending early insight into the menu of decisions available to these customers once they have initial buy-in. 


\section{Methods and Data}

Our analysis relies on privately provided data from an online residential and commercial PV solar marketplace, EnergySage (www.energysage.com). Prospective PV customers submit house-specific information (such as electricity use) and their preferences (such as quality of equipment, financing options like loans and leases) online, and those data are sent to EnergySage's independent installer partners for bids. Installer partners return quotes through the platform, which may contain more than one financing option. If a prospective customer completes a transaction based on one of the bids submitted through EnergySage, the contracted installer pays a service fee. If the customer does not choose any of those quotes (by opting out of PV or choosing a quote outside of EnergySage's platform), no fee is charged. EnergySage's network consists of installers who range from installers that operate on a local and regional scale to a national scale. There was no way for us to know the choices prospective customers faced outside of this platform, and the only ultimate customer decisions we could know were those that resulted in contracting with an EnergySage installer. We do not know the final choices of customers who did not select an EnergySage quote either due to not choosing solar or choosing a quote outside of the EnergySage platform. Figure 2 illustrates the distribution of the number of quotes per property. Note that nearly one-third only receive one quote, close to another third receive two quotes and the remaining third receive three or more quotes. ${ }^{2}$ We have analyzed over 10,000 quotes submitted to approximately 5,000 customers in about 20 states over the $2013-$ 2015 period. Note that if an installer provided a PPA or a lease quote, they often included two financing options - both a zero-down and a prepayment option. In many cases, they also included a cash purchase option.

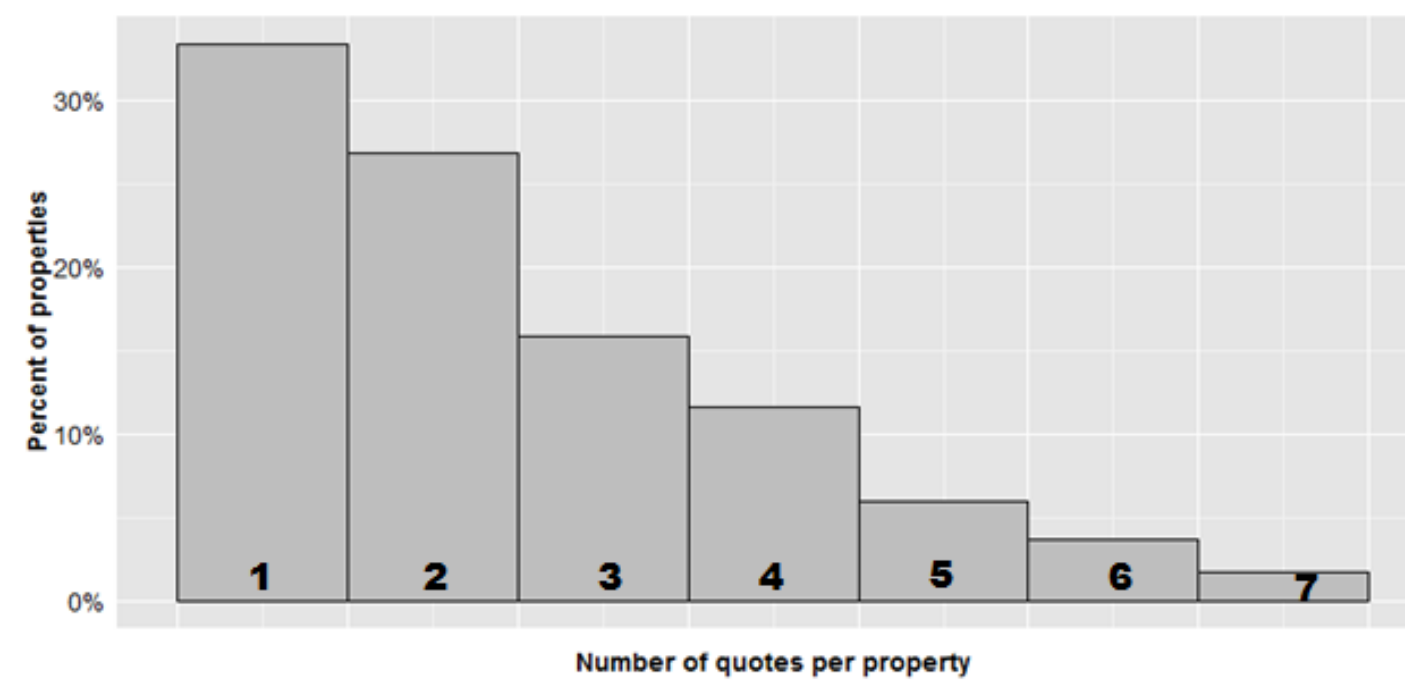

Figure 2. Percentage of properties receiving a given number unique installer quotes (2013-Q3 2015)

Each EnergySage quote includes system size, estimated electricity production, hardware (module and inverter) selection, and ownership model (host or third-party-owned [TPO]). If the system is to be host owned, a quote can include loan provisions. If the system is to be TPO, options include leasing the system or purchasing the electricity generated via a power purchase

\footnotetext{
${ }^{2}$ Reasons for only receiving one quote could include: areas where EnergySage has few partner installers and/or properties that are not optimal for solar.
} 
agreement (PPA), and quotes include the option to prepay the contract and/or commit to a zeromoney-down contract; $76 \%$ of all TPO quotes were zero-down leases, and this proportion rose to $92 \%$ in 2015 . To compare values across disparate quote types, we converted all quotes to a perwatt present value of all payments using a 7\% discount rate for payments accrued after the initial year (Equation 1).

$$
\begin{aligned}
& \text { (1)Real Contract Price }(\$ 2015)_{i} \\
& \qquad=\text { Upfront payment }+\sum_{y=1}^{t}\left[\text { monthly payment } *(1+e)^{y} * 12\right] /\left[(1+d)^{y-1}\right]
\end{aligned}
$$

Where $i=$ the individual contract, $t=$ term length, $y=$ contract year, $e=$ escalation rate, and $d=$ discount rate.

In the case of a PPA, the monthly payment is estimated based on assessed average monthly production stipulated in the contract. ${ }^{3}$ We assume system production declines $0.05 \%$ per year (Jordan and Kurtz 2012) and calculate the estimated monthly payment as follows:

(2) Estimated monthly payment $=$ estimated monthly production $*(0.995)^{y-1} * P P A$ rate

To determine the real contract price for PPAs, estimated monthly payments are escalated annually (when applicable) and summed up over the timeframe of the contract. The contract term is 20 years in $79 \%$ of the TPO quotes.

\footnotetext{
${ }^{3}$ Companies likely rely on varying methods to estimate the average monthly production. We have no way to validate estimated monthly production or evaluate whether estimates are biased upwards or downwards, because this depends on exact location, system design parameters, roof features, and shading.
} 


\section{Results}

In this section, we first present a high-level summary of the full data set-including quoted prices by equipment type, ownership model, and state - for the first three quarters of 2015 . We would expect quotes to vary according to these parameters as they ultimately reflect different installer costs. In addition, we provide statistics on system sizes and the percentage of load the proposed system offsets, by state, as these parameters may be heavily influenced by local factors, including state and utility level regulations, electricity rates and incentives.

Then, we evaluate variation in quotes at the household level to glean insight into decision making process faced by individual households. This section of the analysis used all quotes available but focused on variation within quoted prices, financing options, system sizes, and PV equipment for the same property. As a result, the incentive and regulatory environment is the same - the only factors that vary are the parameters of the quote provided by the installers.

\subsection{High-Level Quote Trends, 2015}

Figure 3 illustrates the distribution of EnergySage residential PV price quotes by state in the first three quarters of 2015. ${ }^{4}$ The distribution does not exactly align with the state ranking of installations nationwide. However, with the exception of Hawaii (where EnergySage is not active), the five states with the largest number of residential PV installations nationwideCalifornia, New York, New Jersey, Massachusetts, and Arizona (GTM Research and SEIA 2015) - are among the top eight states within the EnergySage data.

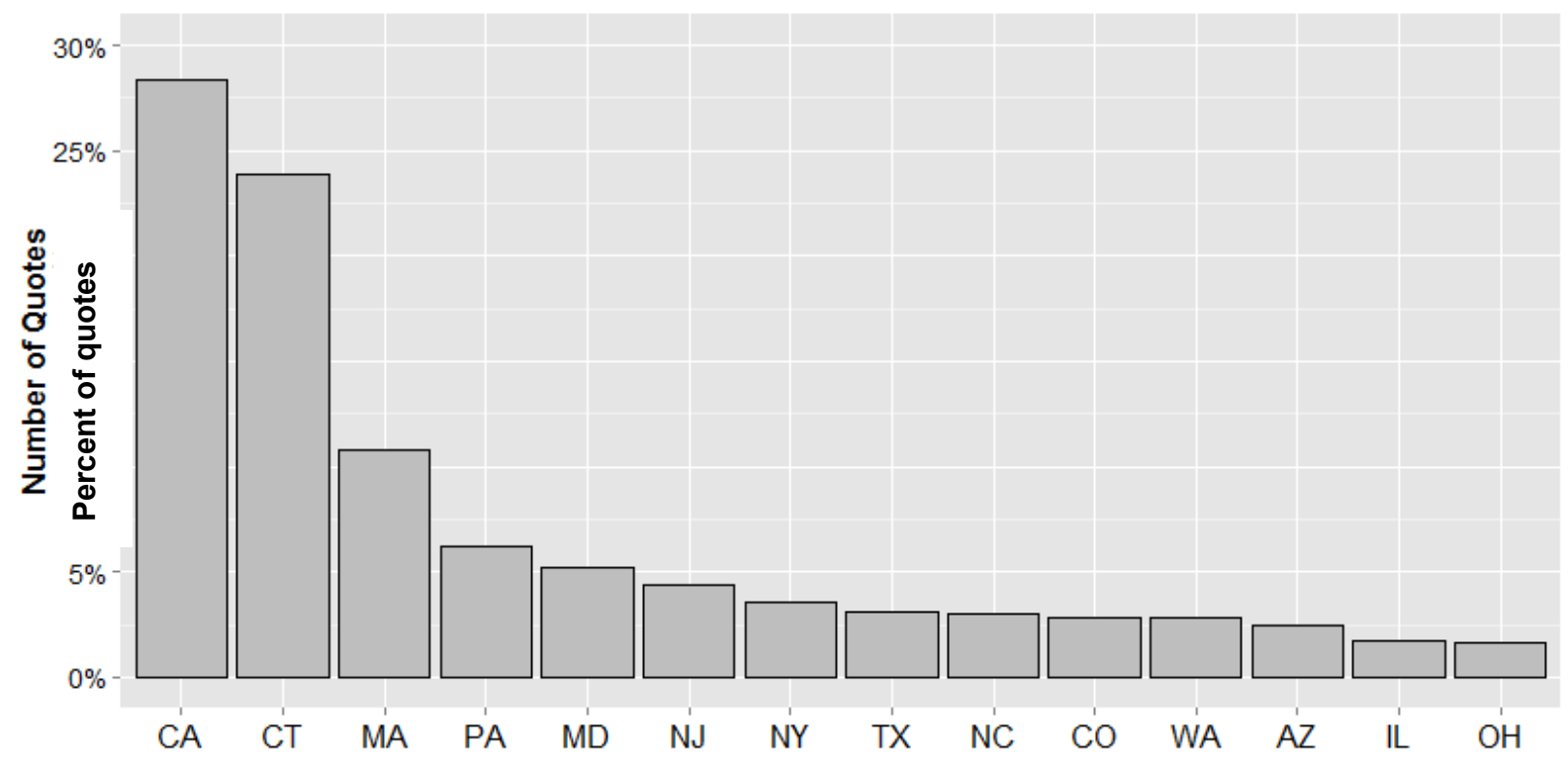

Figure 3. Distribution of EnergySage residential PV price quotes by state, 2015

\footnotetext{
${ }^{4}$ For chart legibility, excludes states with insufficient quote-seekers in 2015, which include Maine, Montana, Iowa, New Mexico, Delaware, Rhode Island, Wisconsin, Washington, D.C., Georgia, Indiana, Missouri, Vermont, South Carolina, Florida, Michigan and, Oregon, Virginia, and New Hampshire.
} 
Across all the data, quote pricing in 2015 varied by hardware selection, state, ownership type, and contract type. Quotes containing high-efficiency panels (greater than 18\% conversion efficiency) were, on average, $\$ 0.70 / \mathrm{W}$ more expensive than those with standard-efficiency panels (Table 1). ${ }^{5}$ Quotes containing optimizers and microinverters were $\$ 0.17$ and $\$ 0.11$ more expensive than string inverters.

Table 1. Average Quote Price by Hardware Type, 2015

\begin{tabular}{lll}
\hline & Mean $\mathbf{( \$ \mathbf { W } )}$ & Percent of quotes \\
\hline High Efficiency & 4.20 & $5 \%$ \\
Standard Efficiency & 3.48 & $95 \%$ \\
Microinverter & 3.57 & $34 \%$ \\
String Inverter & 3.46 & $66 \%$ \\
Optimizer & 3.63 & $23 \%$ \\
\hline
\end{tabular}

Prices varied substantially by contract type, particularly between TPO and host-owned systems. The price of host-owned systems averaged \$1.82/W more than TPO systems through Q3 2015 (Figure 4 and Table 2). Note that incentives remain with the system owner, so in the case of the host-owned system, the owner will later receive a 30\% Investment Tax Credit (ITC) as well as any state and utility incentives. In the case of the TPO system, the commercial owner has the option of passing along the value of any incentives in the form of lower quotes, but the TPO customer will not specifically receive these incentives.

${ }^{5}$ Differences in means stated are statistically significant at $p<1 \%$ unless otherwise stated. 


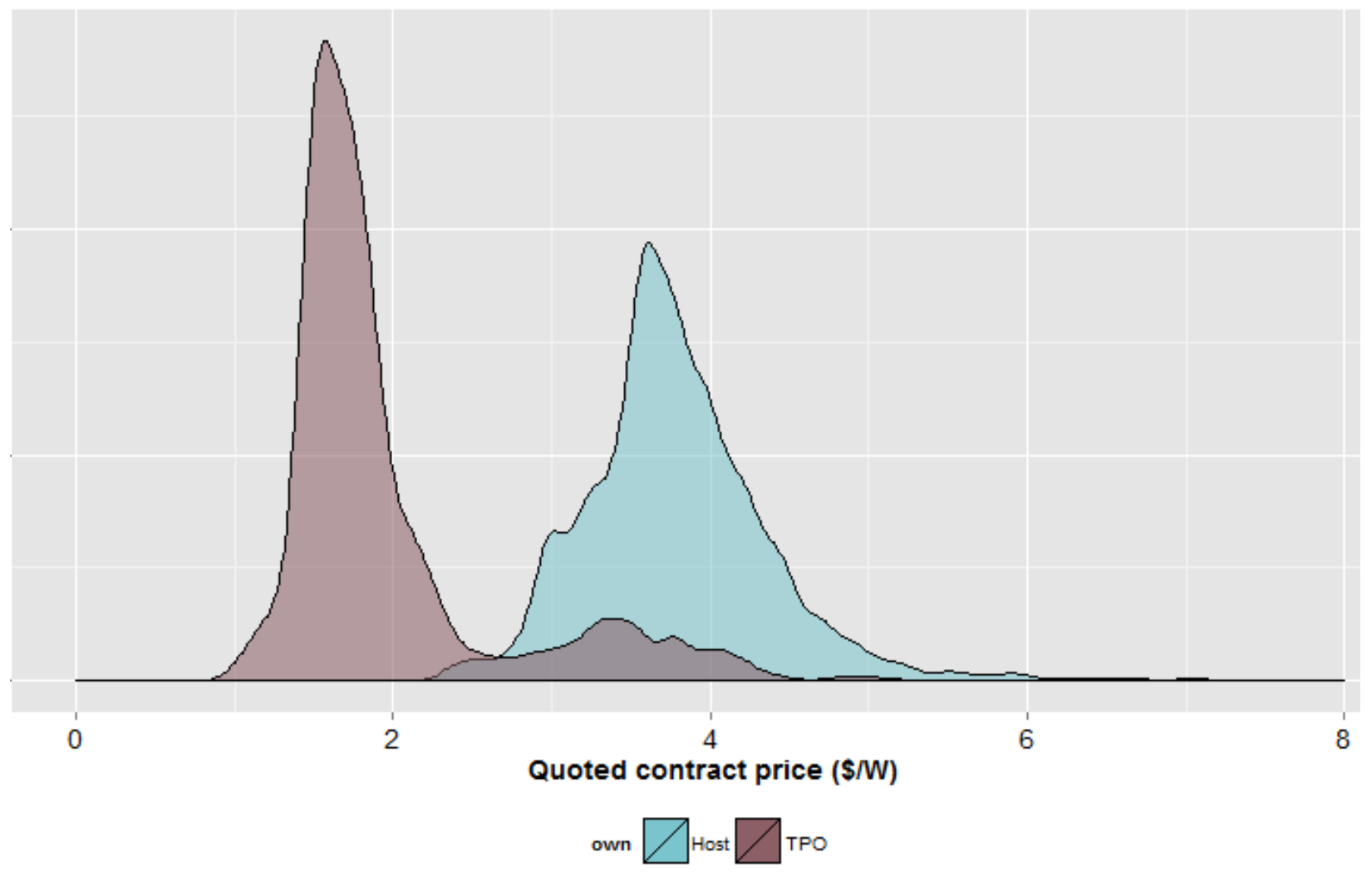

Figure 4. Distribution of residential PV quote prices by ownership type, 2015

Table 2. Mean Residential PV Quote Price by Ownership Type and Year

\begin{tabular}{lll}
\hline & Mean $(\$ / \mathrm{W})$ & Percent of Quotes \\
\hline Host & 3.78 & $83 \%$ \\
TPO & 1.97 & $17 \%$ \\
\hline
\end{tabular}

Quoted prices varied substantially by state, as the boxplots in Figure 5 illustrate, for host-owned systems only. ${ }^{6}$ The box represents the interquartile range $\left(25^{\text {th }}-75^{\text {th }}\right.$ percentile $)$ while the lines extend to the $10^{\text {th }}$ and $90^{\text {th }}$ percentile and the points indicate outliers. The boxes are colored according to whether or not an active Solar Renewable Energy Credit (SREC) market is present. States in the data set with SREC markets generally appeared to have lower prices than states without SREC markets; the exceptions were Massachusetts (with an SREC market), where quotes were among the highest in the data set, and Texas (without an SREC market), where they were among the lowest. SRECs provide an additional revenue stream of $\$ 50-\$ 500 / \mathrm{MWh}$, depending on the state, to the system owner. This should affect TPO prices more than hostowned prices, because the additional SREC revenue the third-party owner receives would enable them to offer lower contract prices while remaining profitable. However, for 2015, data on TPO quotes are insufficient for comparing across SREC and non-SREC states; most TPO quotes were for Connecticut, Maryland, and California.

\footnotetext{
${ }^{6}$ We excluded 4 states (New Hampshire, Illinois, Virginia and Ohio) that did not have more than sufficient observations once the subset was reduced to host owned systems.
} 


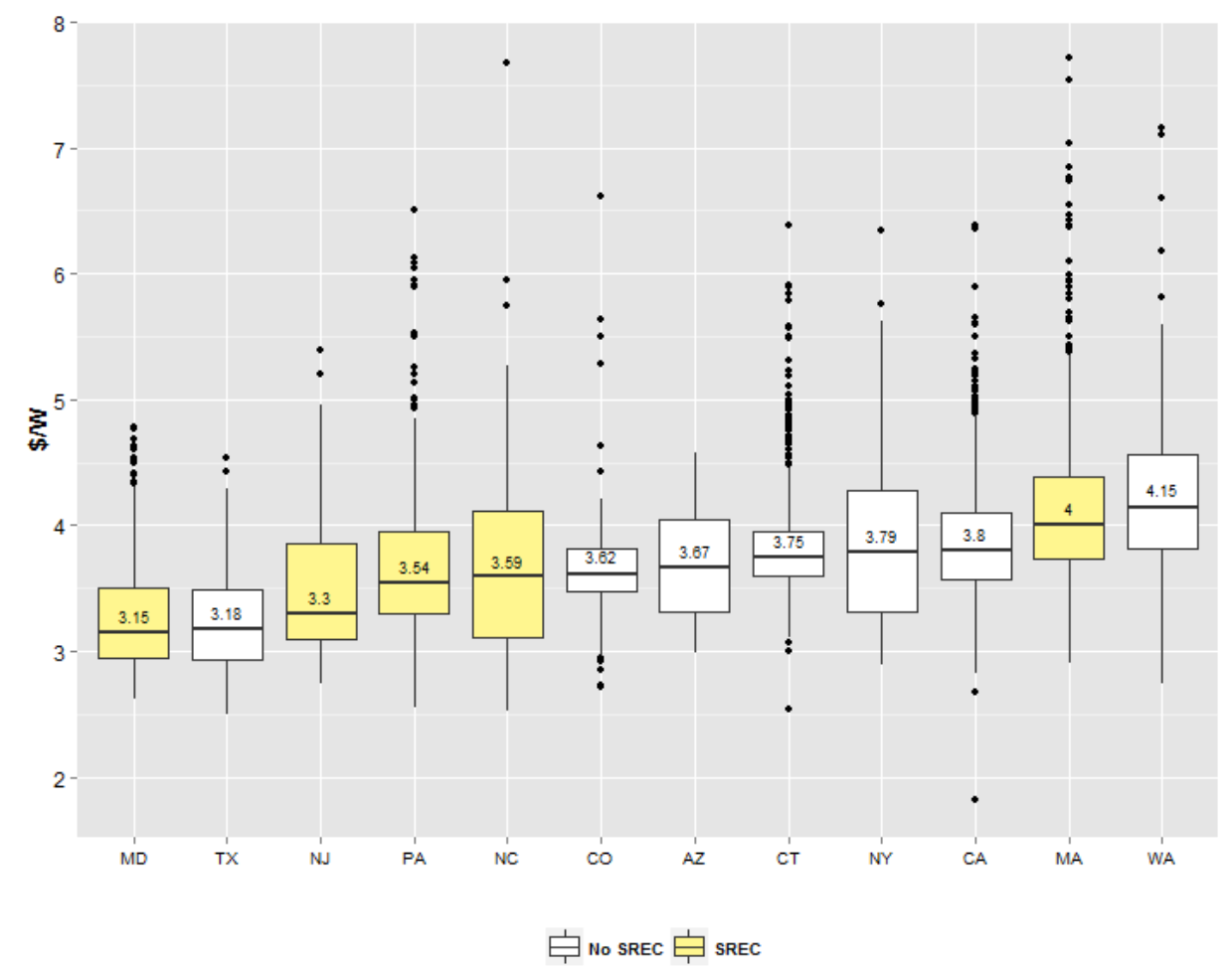

Figure 5. Host-owned residential PV price quotes by state: SREC and non-SREC markets, 2015

To compare with a commonly cited PV price source, Table 3 illustrates median Energy Sage prices for host-owned residential PV systems in 2014 as well as Lawrence Berkeley National Laboratory's 2014 Tracking the Sun price data (Barbose and Darghouth 2015). The Energy Sage quotes are consistently lower (with the exception of Conneticut), and overall ranking differs. This is likely due in part to differences in installer costs, as well as lag time between quote date and install date. The average lead time between customers receiving a quote date and the proposed install date is 60 days, or two months. Quotes may be a leading indicator of the direction that prices are going in a rapidly changing market. 
Table 3. Median Energy Sage and Tracking the Sun (Barbose and Darghouth 2015) Host-Owned Residential PV Prices, 2014

\begin{tabular}{lrr}
\hline State & $\begin{array}{c}\text { Energy } \\
\text { Sage } \\
\mathbf{2 0 1 4}\end{array}$ & $\begin{array}{c}\text { Tracking } \\
\text { the Sun } \\
\mathbf{2 0 1 4}\end{array}$ \\
\hline TX & $\$ 3.28$ & $\$ 3.40$ \\
AZ & $\$ 3.38$ & $\$ 3.60$ \\
PA & $\$ 3.45$ & NA \\
NJ & $\$ 3.50$ & $\$ 3.90$ \\
CO & $\$ 3.57$ & $\$ 3.70$ \\
NC & $\$ 3.62$ & $\$ 4.70$ \\
MD & $\$ 3.68$ & $\$ 3.90$ \\
CT & $\$ 3.92$ & $\$ 3.90$ \\
CA & $\$ 3.92$ & $\$ 4.60$ \\
MA & $\$ 4.00$ & $\$ 4.40$ \\
WA & $\$ 4.15$ & NA \\
NY & $\$ 4.19$ & $\$ 4.80$ \\
\hline
\end{tabular}

System size characteristics also varied by state - both in terms of the system size as well as the implied percentage of a customer's load that the system offsets. Figure 6 illustrates the distribution of load offset, by state, providing the median within the box and whiskers.

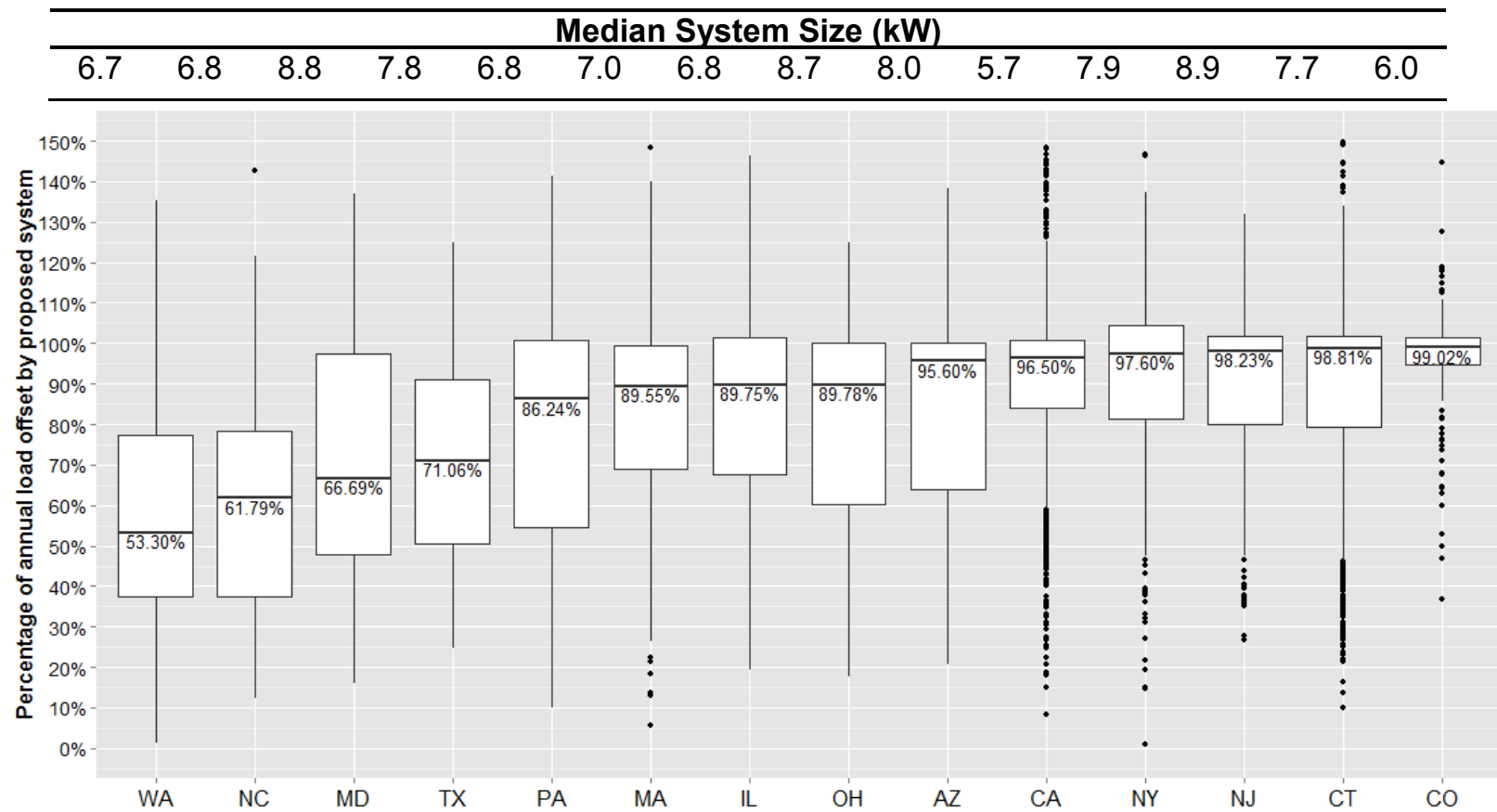

Figure 6. Median System Size and Distribution of Annual Energy Offset, 2015

The percentage of load offset proposed typically depends on local retail rates (for tiered rates, offsetting only expensive tiers may be the most economical), utility regulations (typically limited 
to less than $100 \%$ of annual load), net metering regulations, homeowner and installer sizing preferences.

\subsection{Price Dispersion in PV Quotes}

Typically, price dispersion measures the price range across a homogenous good (Hopkins 2006). Each PV customer quote, however, is a completely independent good, though the referenced property/rooftop is identical. Therefore, it is helpful to characterize the PV price dispersion (on a cost-per-watt basis) for what is essentially the same service. ${ }^{7}$ Figure 7 illustrates two typical price-dispersion metrics: price range and standard deviation. The price range measures the difference between the highest and lowest quoted price for the same property, and the standard deviation is a unit-less measure of variation from the mean of all quotes for the same property. From Q1 2013 to Q2 2015, the quotes received by one property had a standard deviation of 0.95 and a median range of $\$ 1.41 / \mathrm{W} .{ }^{8}$ The large range can be attributed partly to the way $\mathrm{PV}$ tax incentives - particularly the ITC — are monetized under different ownership models: third-party owners reflect the passed-through value of the incentives in their lower contract prices, while host owners pay a higher cash-purchase price and then recover some of that outlay later using tax credits. The blue line in Figure 7 illustrates the range after reducing cash-purchase (i.e., hostowned) quotes by $30 \%$ to reflect the final out-of-pocket cost to the homeowner after receiving the full $30 \%$ ITC on a cash-purchased system (assuming the homeowner can fully deduct the $30 \%$ value from their taxable basis).

\footnotetext{
${ }^{7}$ System components and size vary, and price would be expected to vary accordingly. However, evaluating metrics on a cost-per-watt basis facilitates comparison across system sizes. Different equipment can still result in different production levels.

${ }^{8}$ In the fourth quarter of 2014, EnergySage began to partner with installers in Connecticut, increasing quotes from that state dramatically from the third quarter of 2014 to the first quarter of 2015. Initially, Connecticut installer quotes exhibited an average range of $\$ 2.30 / \mathrm{W}$, explaining the increase in quote range around the fourth quarter of 2014.
} 


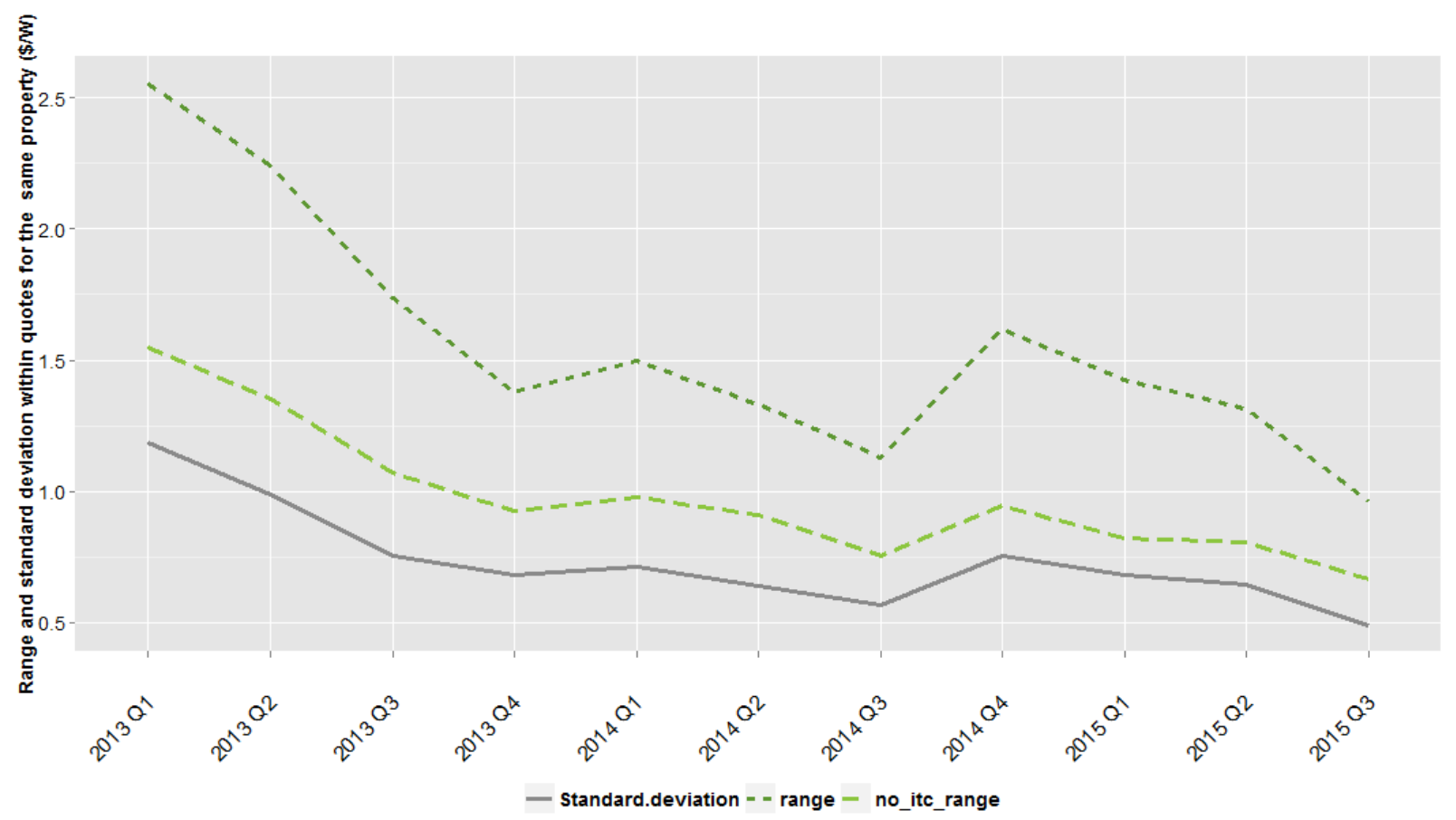

Figure 7. Range and standard deviation of residential PV quotes by property, 2013-Q2 2015

Figure 8 separates distributions of ranges by ownership model. The range of system prices across both ownership models decreased during the 2013-2015 time period to an average of $\$ 0.79 / \mathrm{W}$ (for host-owned systems) and an average of $\$ 0.53 / \mathrm{W}$ (for TPO systems). That is, the percentage of properties with host-owned quote ranges of more than $\$ 1$ decreased from $47 \%$ to $25 \%$ over this time period, while this metric decreased from $53 \%$ to $6 \%$ for properties that received various TPO quotes. 

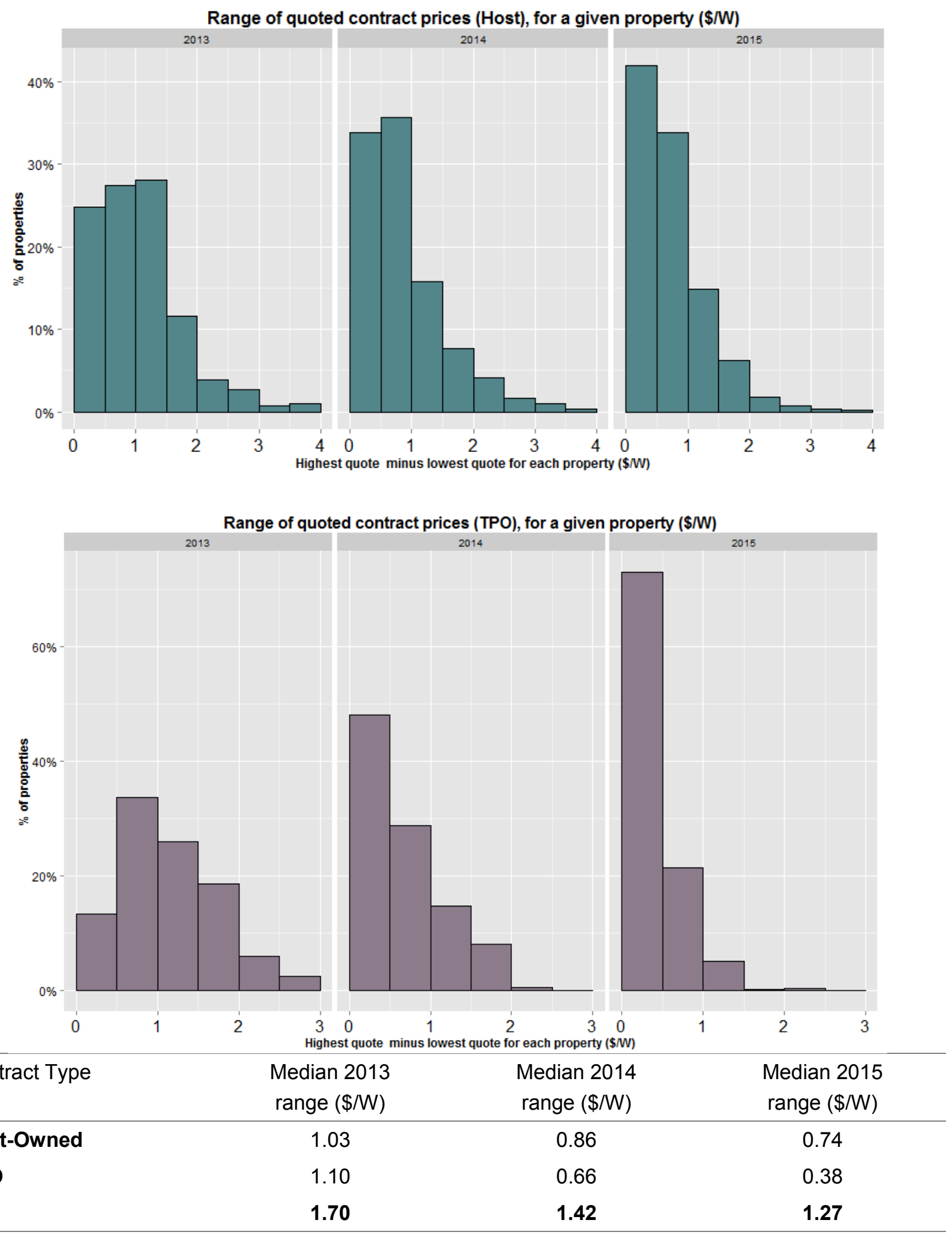

Figure 8. Distribution of quoted residential PV price ranges, by property and ownership model 
Put another way, the price range decreased from $27 \%$ to $19 \%$ of the median host-owned price over the 2013-2015 period and from 55\%-19\% of the median TPO price over the same period. There is no way of knowing the driver of this decrease in dispersion without access to additional data. Possible reasons include: increasing competition, increasing consumer awareness of the marginal cost of specific attributes of PV systems and convergence around the value of PV to a specific homeowner (i.e. providing a fixed discount on current electricity expenditure). All reasons are conjectured; the only clear takeaway is that homeowners likely faced increased price consistency from 2013-2015.

As the market continues to evolve, data like these will allow us to track quote dispersion over a longer time frame. As information related to PV products and the value associated with specific attributes becomes more defined, prices may converge further for similar product offerings.

\subsection{Product Variation in PV Quotes}

When potential PV customers solicit quotes, they present installers with key system-design parameters: available roof space and electric bills. Installers use these parameters to propose system designs that meet a certain portion (typically less than 100\%) of annual customer electricity demand. Installers often have design preferences, such as prioritizing aesthetics or a certain array shape (boxes or rectangles) over maximum panel coverage. Maximizing coverage often requires performance tradeoffs, for example, requiring micro inverters for partially shaded panels. Finally, installers may aim to provide consistently sized packages, for example, providing systems in increments of $1.5 \mathrm{~kW}$. As a result, a potential customer soliciting multiple installers will receive quotes exhibiting a wide range of sizes, hardware selections, and configurations. The EnergySage data set gives us a unique opportunity to characterize the range of options provided to customers.

\subsubsection{System Size Variation}

Figure 9 suggests that prospective customers face a wide range of proposed system sizes for the same roof and electric bill. On average over the 3 years, quotes for a given property had a range of $2 \mathrm{~kW}$ between the highest and lowest quoted capacity; based on an average quote price of $\$ 3.50 / \mathrm{W}$, such a range produces a potential difference of $\$ 7,000$ in total cash outlay-a substantial sum for most residential customers. This range declined slightly over the 3-year period, from an average of $2.2 \mathrm{~kW}$ in 2013 to $1.8 \mathrm{~kW}$ in 2015. Similarly, the range in the percentage of load offset by the quoted system for a given property declined from $18.8 \%$ in 2013 to $16.5 \%$ in 2015. 


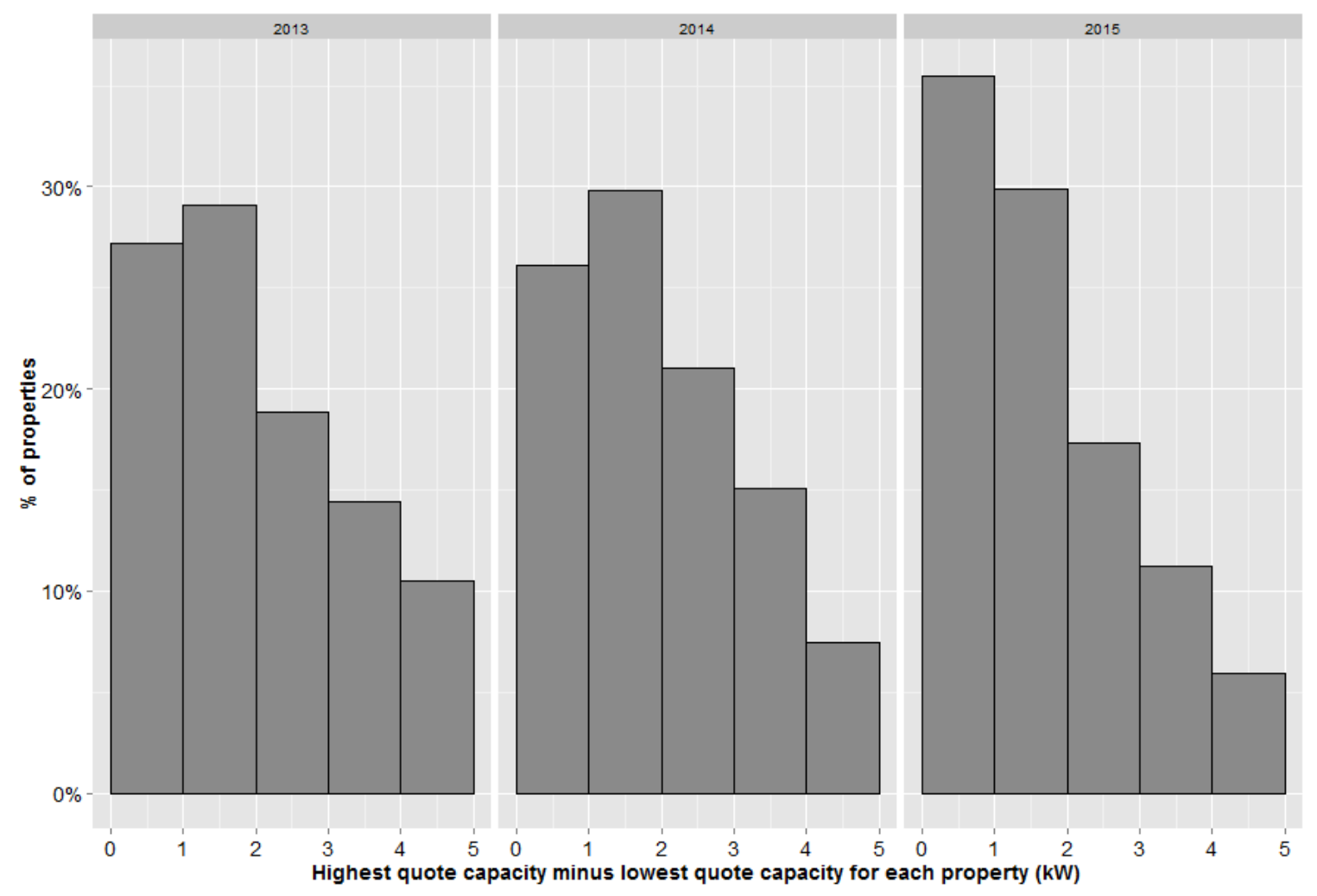

Figure 9. Range of quoted residential PV system sizes, for a given property

How customers choose from among a range of potential system sizes affects the value they derive from their PV systems. The optimal system size - and thus the optimal proportion of electricity load offset-depends on current rate structures, household load growth, and changes in utility rates and net-metering regulations over the system's lifetime. Because some of this information is unknown, system-size choices are influenced by customer risk tolerance and expectations of future conditions as well as installer recommendations.

\subsubsection{Equipment Variation}

Finally, many equipment choices can be considered relatively homogenous; for example, most installers supply Tier 1 modules with efficiencies of $14 \%-16 \% .{ }^{9}$ Furthermore, many stringinverter makes and models as well as racking products perform the same functions for approximately the same price. However, a few products yield production differences and would be expected to carry a corresponding price difference, including high-efficiency modules, microinverters, and optimizers (Table 1). Across our data sample, $42 \%$ of prospective customers received at least one quote with standard equipment and at least one quote with non-standard equipment. We did find a statistically significant price difference between high and standard efficiency modules; in some cases, high efficiency modules can have performance benefits that may justify the additional expenditure. However, quotes that offer these products require the prospective customer to obtain and process additional information for comparison with standard systems, which might present an additional barrier to decision making.

\footnotetext{
${ }^{9}$ Based on data from the Open PV Project (https://openpv.nrel.gov/).
} 


\section{Discussion}

The EnergySage price quotes provide new, data-driven insights into the decision making process required to obtain rooftop PV. A typical prospective customer must evaluate many product bundles with a large range of attribute combinations, including variable system prices, ownership models, system sizes, and equipment selections. Major findings from our analysis of these data include the following:

- Residential properties exhibited a median range of $\$ 1.41 / \mathrm{W}$ in quoted prices during 2013-2015. The range decreased during this period: to a range of $\$ 0.79 / \mathrm{W}$ (for hostowned systems) and \$0.54/W (for TPO systems) in 2015.

- On average during 2013-2015, quotes for a given residential property had a range of 2 $\mathrm{kW}$ between the highest and lowest quoted capacity. The range declined over this period from an average of $2.2 \mathrm{~kW}$ in 2013 to $1.8 \mathrm{~kW}$ in 2015 . These differences were significant at less than $1 \%$.

- Nearly half of the residential properties (42\%) received at least one quote for nonstandard equipment (high-efficiency panels, microinverters, or optimizers) in addition to a quote for standard equipment, which might have complicated decision making.

Even after a customer expresses initial interest in PV, the process of choosing a particular PV system is complex. Residential PV customers are not like the energy professionals - trained in evaluating a variety of tradeoffs - who make decisions about central generation technologies. A household's decision to install PV entails unique considerations and barriers. For example, adopting PV is only one of hundreds of decisions competing for a household's time and capital - and PV is a particularly long-term, high-expenditure investment for most households. Further, PV remains an alternative to the status quo: grid-supplied electricity, that is, a discretionary purchase. Reducing the variation within quotes for a given property could reduce the information required to make an informed decision, streamlining the purchase choice. Our results show declining quote-price and system-size ranges for a given property over time at least within the EnergySage data. It is not clear whether this is a result of price discovery around specific attributes of PV systems, a general convergence of PV prices around the value of PV for a particular household (resulting from retail rates or available incentives), or some other factor.

Our results are limited by the fact that the quote data cover only a short period, and the numbers and geographies of quote contributors (i.e., installers) varied substantially over the course of this period. As the data continue to grow, EnergySage and other quote-data sources likely will provide increasing insights into the progress toward standard, transparent, and consistent PV pricing. In addition, we may be able to glean insights into why customers selected specific quotes, particularly if this is combined with customer surveys to understand alternatives outside of the quote platform. 


\section{References}

Bakos, Y. 1997. "Reducing Buyer Search Costs: Implications for Electronic Marketplaces." Management Science 43(12): 1676-92.

Barbose, Galen, and Naïm Darghouth. 2015. Tracking the Sun VIII: The Installed Price of Residential and Non-Residential Photovoltaic Systems in the United States. Berkeley, CA: Lawrence Berkeley National Laboratory.

Bollinger, B., and K. Gillingham. 2012. "Peer Effects in the Diffusion of Solar Photovoltaic Panels.” Marketing Science 31: 800-12.

Chiang, J.P. 2006. "Clicking Instead of Walking: Consumers Searching for Information in the Electronic Marketplace.” ASIS Bulletin, January.

Davidson, C., and D. Steinberg. 2013. "Evaluating the Impact of Third-Party Price Reporting and other Drivers on Residential Photovoltaic Price Estimates." Energy Policy 62: 752-61.

Davidson, C., D. Steinberg, and R. Margolis. 2015. "Exploring the Market for Third-PartyOwned Residential Photovoltaic Systems: Insights from Lease and Power-Purchase Agreement Contract Structures and Costs in California.” Environmental Research Letters 10: 024006.

Dinerstein, Michael, Liran Einav, Jonathan Levin, and Neel Sundaresan. 2014. "Consumer Search, Pricing and Platform Design in Online Markets." National Bureau of Economic Research Working Paper.

Gillingham, K., H. Deng, R. Wiser, N. Darghouth, G. Nemet, G. Barbose, V. Rai, and C. Dong. 2014. Deconstructing Solar Photovoltaic Pricing: The Role of Market Structure, Technology and Policy. Berkeley, CA: Lawrence Berkeley National Laboratory.

GTM Research. 2015. U.S. Residential Solar Financing: 2015-2019. Boston: GTM Research.

GTM Research and SEIA (Solar Energy Industries Association). 2015. U.S. Solar Market Insight 2014 Year-in-Review. Boston: GTM Research and Solar Energy Industries Association.

Hopkins, E. 2006. "Price Dispersion.” ESE Discussion Papers. Edinburgh School of Economics, University of Edinburgh.

Jordan, D.C., and S.R. Kurtz. 2012. "Photovoltaic Degradation Rates—an Analytical Review." Progress in Photovoltaics 21: 12-29.

Noll, D., C. Dawes, and V. Rai. 2014. "Solar Community Organizations and Active Peer Effects in the Adoption of Residential PV." Energy Policy 67: 330-43.

Rai, V., and K. McAndrews. 2012. "Decision-Making and Behavior Change in Residential Adopters of PV." Paper presented at the World Renewable Energy Forum, American Solar Energy Society, May 2012. 
Rai, V., and S.A. Robinson. 2013. "Effective Information Channels for Reducing Costs of Environmentally-Friendly Technologies: Evidence from Residential PV Markets." Environmental Research Letters 8: 014044.

U.S. Department of Commerce. 2015. 2010 Census of Housing. http://www.census.gov/2010census/data/ Accessed 9/15/2015. 